\title{
EL ESPAÑOL ALBERT CAMUS
}

\author{
JAVIER FIGUERO
}

¿Por qué Camus?... Primero porque forma parte de mi educación sentimental. Recuerdo todavía la muerte de Albert Camus, enero de 1960. Una sucinta noticia leída en la prensa en la que se daba cuenta de la muerte en accidente de carretera de un escritor de 47 años, francés de Argelia y con madre española. Era premio Nobel de Literatura y en las clases del bachillerato elemental que cursaba entonces nunca oí su nombre. Con el tiempo sus libros formaron parte de mis lecturas recurrentes. Ediciones sudamericanas primero, conseguidas fuera de los circuitos comerciales donde el franquismo le marginaba. Descubrí que sus escritos transmitían valores que dignificaban al hombre.

Como otros jóvenes de su generación, Camus fue convocado por la vida a las grandes tragedias guerreras del siglo pasado: la guerra civil española y la segunda guerra mundial, por no hablar de la primera en que murió su padre cuando él era sólo un bebé. Pero, lejos del nihilismo o pesimismo en que cayeron otros intelectuales, supo transmitir un mensaje de dignificación del hombre. Se trataba de conciliar la justicia y la libertad y había que ser intransigente en la consecución de ambos logros. Se vivió en el gran absurdo y ya no se podía ser sino rebelde, solidario y comprometido. Él es un ejemplo de compromiso. Lo ejerció no ya en tanto que artista, sino en tanto que hombre, tal y como dijo en la recogida del premio Nobel, hace ahora sesenta años. Un compromiso excepcional con la España republicana.

La madre es el centro de su obra creativa. Lo dice en el prefacio de la reedición de Gallimard de L'envers et l'endroit (1958) donde hace balance de la misma. Fue la incomprensión de su indiferencia lo que le animó a equilibrarla con la búsqueda de una justicia o un amor que lo compensara. "Una obra de hombre", sentenció ahí, "no es otra cosa que una larga marcha para recuperar las dos o tres simples y grandes imágenes a la que se abrió el corazón por primera vez". El suyo, se cerraría con lo mismo: él es el Jacques Cormery de Le premier homme. 
Pero la idea está ya en las más tempranas notas de sus Carnets donde se compromete a expresar su obra futura por intermedio de la madre y el hijo pues su amor por ella expresa toda su sensibilidad. La obra de Camus es un diálogo permanente con la madre.

No dejó de escribirle: L'Étranger, L'envers et l'endroit, Le Malentendu, L'état de siège, La Peste... Por eso, su gran amor, la actriz María Casares, española, gloria de la escena francesa del último cuarto del siglo XX, acaba siendo un amor maternal. Ella será España, como lo fue la madre. Muerto su padre francés cuando contaba pocos meses, Camus no conoció otra familia que la española de la madre. Amaba a mi madre con "desesperación" escribirá en los Carnets. Palabra que utiliza para expresar su sentimiento por España en el prólogo de ¡España libre!... Tras un periodo de indolencia juvenil amó más a su madre y a todo lo que representaba, España desde luego. A las dos las ve "esclavizadas" (por enfermedad, la una; por el franquismo, la otra) y le "angustia”. España, asegura ahí, es "tierra de grandeza", la "única tierra" con la que se siente "plenamente de acuerdo".

En plena guerra civil entonces, desde sus inicios en Argel como periodista Camus sufrió su drama "como una tragedia propia", y limpiar la humillación que le infringieron los enemigos de la libertad fue ya motivación insoslayable, y la frustración más amarga de su vida, junto a la de Argelia. Irresponsables con "el más orgullos de los pueblos", con la nación en que cobró "sentido el honor", el escritor avergonzó a las aliadas en la Guerra Mundial porque Europa nada sería "nunca sin España". Pertinaz enemigo del militarismo que la "esclavizó", de la Iglesia que "santificó" el despropósito, del Occidente vergonzante, Camus alzó incansable su voz por "la única tierra” con la que se sabía "plenamente de acuerdo". Así dejó creaciones imperecederas a su mayor gloria, movilizó a grandes intelectuales franceses y foráneos y se involucró en las iniciativas del exilio republicano español como si de algo propio se tratará. Fue "un Quijote", dijo de él Salvador de Madariaga, "uno de los nuestros", y el largo y profundo amor que le unió a la gran actriz española María Casares resultó también la exquisita representación de su amor por 
España. Desde su condición de extranjero, el compromiso que le ligó a la España que sabía "eterna" no tiene precedente.

De regreso a París desde Estocolmo, donde recibió el premio Nobel de Literatura, Albert Camus se reunió el 22 de enero de 1958 con los republicanos españoles para decirles: "No os abandonaré jamás y seré siempre fiel a vuestra causa”. Distanciado de los intelectuales franceses que fueron sus amigos por la incomprensión de su postura ante la guerra de Argelia, Camus rechazó antes todos los homenajes en Francia, pero era de "la misma sangre" que esos interlocutores y sentía por España, "su literatura, su pueblo y su tradición, una deuda” que no se extinguiría “jamás”. No fue un gesto aislado.

Mi libro Albert Camus, exaltación de España (Editorial Planeta) responde a un doble propósito: seguir al hidalgo Camus en el empeño disparatado y terco de incordiar a los gigantes que afrentaron en vida la tierra de sus mayores, la suya también, un camino que no tuvo hasta ahora narrador; y analizar el enorme débito que su literatura dejó en la obra del Nobel, iniciativa no abordada en la magna ensayística que hasta el momento inspirara. La comprensión de la misma será otra a partir de este libro. Tras él se podrá decir en verdad que Albert Camus fue un español; esto es, "uno de los nuestros". 


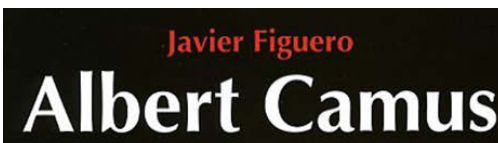

Javier Figuero

Albert Camus, exaltación de España

ou l'Espagne exaltée

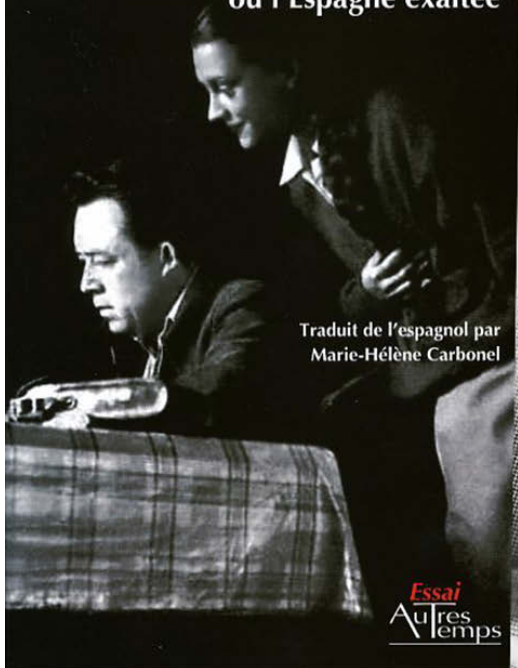

EspañaEscrita: Desde su condición de aextranjeron, el compromiso que

ligó a Albert Camus a la España que sabía ecternas no tiene precedente.

¿s uno de los nuestros», dijeron de él los republicanos exiliados.

Traduit de l'espagnol par Marie-Hélène Carbonel
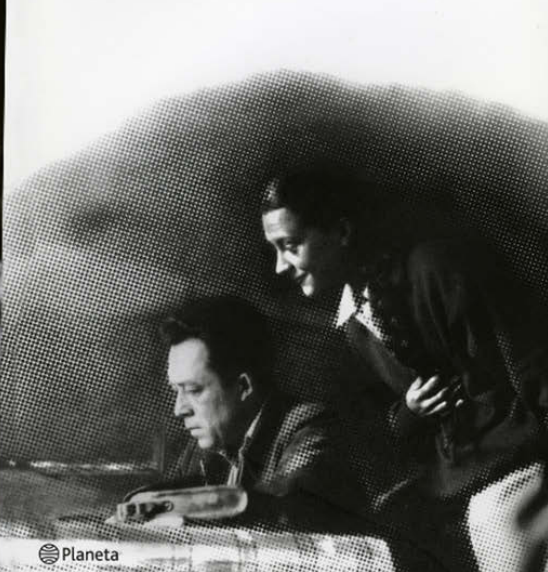